\title{
Az első két sikeres, convalescens friss fagyasztott plazmával történő terápia hazai alkalmazása intenzív osztályon kezelt, kritikus állapotú, COVID-19-fertőzésben szenvedő betegekben
}

\author{
Bobek Ilona dr. ${ }^{* 1}$ - Gopcsa László dr. ${ }^{* 2}$ - Réti Marienn $\mathrm{dr} .{ }^{3}$ \\ Bekő Gabriella dr. ${ }^{4}$. Hancz Lilla dr. ${ }^{1}$. Lakatos Botond dr. ${ }^{5}$ \\ Molnár Eszter dr. ${ }^{1}$. Nagy Sándor dr. ${ }^{6}$ - Reményi Péter $\mathrm{dr}^{2}{ }^{2}$ \\ Sebestyén Gabriella dr. ${ }^{1}$ - Sinkó János dr. ${ }^{2}$ - Szlávik János dr. ${ }^{5}$ \\ Szolnoky Miklós dr. ${ }^{7}$. Vályi-Nagy István dr. ${ }^{1,5}$
}
${ }^{1}$ Dél-pesti Centrumkórház, Országos Hematológiai és Infektológiai Intézet, Intenzív Terápiás Osztály, Budapest ${ }^{2}$ Dél-pesti Centrumkórház, Országos Hematológiai és Infektológiai Intézet,
Hematológiai és Őssejt-transzplantációs Osztály, Budapest
${ }^{3}$ Dél-pesti Centrumkórház, Országos Hematológiai és Infektológiai Intézet,
Hematológiai és Őssejt-transzplantációs Osztály, Apheresis és Őssejt-feldolgozó Részleg, Budapest
${ }^{4}$ Dél-pesti Centrumkórház, Országos Hematológiai és Infektológiai Intézet, Központi Laboratórium, Budapest
${ }^{5}$ Dél-pesti Centrumkórház, Országos Hematológiai és Infektológiai Intézet, Infektológiai Osztály, Budapest
${ }^{6}$ Országos Vérellátó Szolgálat, Budapest
${ }^{7}$ Biotest Hungaria Kft., Törökbálint

Bevezetés: Jelenleg nem áll rendelkezésünkre specifikus kuratív kezelés vagy vakcina az új koronavírus-2 (COVID-19, SARS-CoV-2) kezelésére. A súlyos citokinvihar-szindrómával társuló COVID-19-fertôzés kezelésére sürgősen szükséges alternatív kezelési megoldást találni.

Célkitüzés: A convalescens plazmaterápia alkalmazása más, súlyos vírusfertőzések kezelésében a túlélés javulását eredményezte, és ígéretes terápiás megközelítés lehet súlyos COVID-19-betegek számára.

Módszer: Két kritikus állapotú, COVID-19-fertőzött beteg convalescens friss fagyasztott plazmával történő kezelését mutatjuk be.

Eredmények: A plazmaterápia megkezdésekor mindkét beteg gépi lélegeztetésre szorult, és antivirális kezelésben, valamint maximális szupportív ellátásban részesült. A COVID-19-fertőzésból nemrég felépült és a súlyos akut légúti distressz szindrómát okozó koronavírus-2 elleni immunglobulin-G-t termelő donorokból $3 \times 200$ ml convalescens plazma transzfúzióját alkalmaztuk. A convalescens plazma transzfúzióját követően mindkét betegnél javult az oxigénszaturáció, és a gyulladásos értékeket jelző paraméterek csökkenést mutattak. A convalescens plazma adását megelőző paraméterekhez viszonyítva növekedett a lymphocytaszám, és csökkent az interleukin-6-szint. Mindkét betegnél 2 héten belül megszüntethető volt a gépi lélegeztetés. Nem észleltünk a convalescens plazma adása során súlyos mellékhatást.

Következtetések: Megfigyelésünk alapján a convalescens plazmával történő terápia jól tolerálható volt, és javíthatja a betegek gyógyulási arányát. A convalescens plazmával való kezelés optimális dózisának, időpontjának és klinikai előnyeinek meghatározására további nagy, kontrollált vizsgálatok szükségesek. Közleményünk megírásának célja az első két, hazánkban convalescens plazmával sikeresen kezelt, kritikus állapotú COVID-19-fertőzött beteg kórtörténetének bemutatása.

Orv Hetil. 2020; 161(27): 1111-1121.

Kulcsszavak: COVID-19, SARS-CoV-2, convalescens plazma, interleukin-6

*Megosztott első szerzők 


\title{
Successful administration of convalescent plasma in critically ill COVID-19 patients in Hungary: the first two cases
}

\begin{abstract}
Introduction: At present, neither specific curative treatment nor vaccines for novel coronavirus 2019 (COVID-19) are available. There is an urgent need to look for alternative strategies for COVID-19 treatment especially in the case of severe and/or critically ill patients with cytokine release syndrome (CRS).

Aim: Convalescent plasma proved to increase survival rates in other severe viral infections. Therefore, convalescent plasma could be a promising treatment option for severe COVID-19 patients.

Method: In our article, we present the first two critically ill Hungarian patients with COVID-19 infection treated with convalescent fresh frozen plasma.

Results: At the time of plasma therapy both patients were on mechanical ventilation and received antiviral agents and a full scale of supportive care. Each patient received $3 \times 200 \mathrm{~mL}$ of convalescent plasma of recently recovered donors with sufficient novel anti-coronavirus IgG titers. Subsequent to convalescent plasma infusion, oxygenization improved and inflammatory markers decreased in both individuals. As compared to pretransfusion, lymphocyte counts increased and interleukin- 6 level lessened. Both patients were weaned from mechanical ventilation within 2 weeks of treatment. No severe adverse effects were observed.

Conclusions: Our experience indicates that convalescent plasma therapy is well tolerated and could potentially improve clinical outcomes. Optimal dose and timing as well as precise assessment of clinical benefit of convalescent plasma therapy will need further investigation in larger, well-controlled trials. This is the first report of the successful use of convalescent plasma in the treatment of critically ill patients with COVID-19 infection in Hungary.
\end{abstract}

Keywords: COVID-19, SARS-CoV-2, convalescent plasma, interleukin-6

Bobek I, Gopcsa L, Réti M, Bekő G, Hancz L, Lakatos B, Molnár E, Nagy S, Reményi P, Sebestyén G, Sinkó J, Szlávik J, Szolnoky M, Vályi-Nagy I. [Successful administration of convalescent plasma in critically ill COVID-19 patients in Hungary: the first two cases]. Orv Hetil. 2020; 161(27): 1111-1121.

(Beérkezett: 2020. május 13.; elfogadva: 2020. május 15.)

\section{Rövidítések}

ADCC $=($ antibody-dependent cellular cytotoxicity $)$ antitestfüggő sejtközvetített citotoxicitás; ADCP = (antibody-dependent cellular phagocytosis) antitestfüggő cellularis phagocytosis; $\mathrm{ADE}=$ (antibody-dependent enhancement) antitestfüggő erősítés; ARDS $=$ (acute respiratory distress syndrome) akut légúti distressz szindróma; BIKE = bispecifikus monoklonális antitestek; $\mathrm{CAR}=($ chimeric antigen receptor $)$ kimerikus antigénreceptor; CONTARST = COmparing Novel Treatment strategies Against SARS-CoV-Two; COPD = (chronic obstructive pulmonary disease) krónikus obstruktív tüdóbetegség; COVID-19 = (coronavirus disease 2019) koronavírusbetegség 2019; COVID-19-FFP = COVID-19-fertőzésen átesett betegektől származó convalescens friss fagyasztott plazma; $\mathrm{CP}=$ convalescens plazma $\mathrm{CRP}=\mathrm{C}$-reaktív protein; $\mathrm{CRS}=$ (cytokine release syndrome) citokinvihar-szindróma; $\mathrm{CT}=$ (computed tomography) számítógépes tomográfia; DPC-OHII = Dél-pesti Centrumkórház, Országos Hematológiai és Infektológiai Intézet; EIA = enzim-immunoassay; ELISA $=$ (enzyme-linked immunosorbent assay) enzimhez kapcsolt immunszorbens-vizsgálat; ETT = Egészségügyi Tudományos Tanács; FDA = (U.S. Food and Drug Administration $)$ az USA Élelmiszer-biztonsági és Gyógyszerészeti Hivatala; $\mathrm{FFP}=$ friss fagyasztott plazma; GGO $=$ (ground-glass opacity $)$ tejüveghomály; hCHQ = (hydroxychloroquine $)$ hidroxiklorokin; $\mathrm{HIV}=$ (human immunodeficiency virus) emberi immunhiányt előidéző vírus; $\operatorname{IgA}=$ immunglobulin $\mathrm{A} ; \mathrm{IgG}=$ immunglobulin-G; IgM = immunglobulin M; IL6 = interleukin-6; IVIG = intravénás immunglobulin; JAK $/$ STAT = (Janus kinase/signal transducers and activators of transcription) Janus- kináz/szignáltranszduktorok és transzkripciós aktivátorok; LDH = laktátdehidrogenáz; LMWH = (low-molecular-weight heparin) kis molekulatömegü heparin; MERS $=($ Middle East respiratory syndrome) közel-keleti légzési szindróma; NNK = Nemzeti Népegészségügyi Központ; OMSZ = Országos Mentőszolgálat; OVSZ = Országos Vérellátó Szolgálat; $\mathrm{PaO}_{2} / \mathrm{FiO}_{2}$ $=($ partial pressure of oxygen $/$ fraction inspired oxygen $)$ parciális oxigénnyomás/belélegzett $\mathrm{O}_{2}$-koncentráció; PCR = (polymerase chain reaction) polimeráz-láncreakció; RNS = ribonukleinsav; SARS $=$ (severe acute respiratory syndrome $)$ súlyos akut légzőszervi tünetegyüttes; SARS-CoV-1 = (severe acute respiratory syndrome coronavirus l) súlyos akut légzőszervi tünetegyüttest okozó koronavírus-1; SARS-CoV-2 = (severe acute respiratory syndrome coronavirus 2) súlyos akut légzôszervi tünetegyüttest okozó koronavírus-2; sHLH/MAS = (secondary hemophagocytic lymphohistiocytosis/macrophage activation syndrome) másodlagos haemophagocytás lymphohistiocytosis/macrophagaktivációs szindróma; TACO = (transfusion-associated circulatory overload) transzfúzióhoz kapcsolódó keringés-túlterhelés; TRALI $=$ (transfusion-related acute lung injury) transzfúzióhoz kapcsolódó heveny tüdősérülés; TUKEB = Tudományos és Kutatásetikai Bizottság; $\mathrm{USA}=($ United States of America $)$ Amerikai Egyesült Államok

A járványosan először a kínai Vuhanban megjelenő új koronavírus-betegség 2019 (COVID-19) gyorsan terjed világszerte. Jelenleg nincs elérhető kuratív terápia vagy vakcina a COVID-19-fertőzés leküzdésében [1]. Ráadásul a halálos kimenetelű esetek száma is gyorsan 
növekszik világszerte, ezért a súlyos szövődmények kezelések hatékony gyógymódjának megtalálása meglehetősen sürgős kérdés [1]. A publikáció írásának idején, 2020. május 1l-én Magyarországon 3284 COVID19-fertőzött esetet regisztráltak, és 421 fertőzött meghalt; a becsült halálozási arány $12,8 \%$-nak adódik. A súlyos és kritikus COVID-19-esetek klinikopatológiai vizsgálata során egyértelmúen bizonyítást nyert a citokinvihar-szindróma (cytokine release syndrome, CRS) fennállása [1-3]. A CRS jelenléte két további meggondoláshoz vezetett. Először is az új terápiás módszerek térhódítása a hematológiai és őssejt-transzplantációs gyakorlatban, úgymint a bispecifikus monoklonális antitestekkel (BIKE), a haploidentikus őssejt transzplantációjával és a kimerikus antigénreceptort tartalmazó T-sejttel (CAR-T-sejt) való kezelés - a saját gyakorlatunkban is - előtérbe hozta a CRS megismerését és hatékony kezelését [4]. Ezen esetekben a CRS kialakulásának patomechanizmusa sem teljesen ismert, de az interleukin-6 (IL6)-ellenes monoklonális antitesttel, a tocilizumabbal való kezelés hatékony terápiás megoldásnak bizonyult. Másodszor, visszatekintve a SARS-CoV-1, a MERS, a HINl és a H5Nl okozta súlyos komplikációkra: az akut légúti distressz szindróma (ARDS), a hypercytokinaemia kirajzolja, hogy a fenti esetekben is CRS-sel álltunk szemben $[1,5,6]$. A COVID-19-CRS-hez társult ARDS kezelésében - a jelenleg is folyó randomizált vizsgálatok eredményei ismeretének hiányában is - számos terápiás tapasztalatot szereztek világszerte $[2,3]$. Ilyen terápiás megfontolás lehet a korábban említett tocilizumab mellett egyéb monoklonális antitesttel történő terápia (ILl, tumornekrózisfaktor-alfa), a Janus-kináz-gátlás (JAK/STAT), a nagy dózisú intravénás immunglobulin és a COVID-19-fertőzésból meggyógyult donorokból származó convalescens plazma (CP) alkalmazása [4]. A fenti terápiás modalitások befolyásolják a hypercytokinaemiát és a vírusclearance-t.

A CP adásának története az 1890-es években keződött. Alkalmazásához mindig csak ún. vészhelyzet esetén nyúlt az orvostudomány, olyan súlyos, elsősorban virális fertőzésekben, amelyekben megállapított hatékony terápia nem állt rendelkezésünkre [1]. Az ún. békebeli időkben sehol nem végeztek kontrollált vizsgálatot a $C P$ hatékonyságának felmérésére, ennek megfelelően alkalmazásának módja, pontos dózisa, biztonságossága, hatékonyságának felmérése és részletes kiértékelése soha sem következett be. Az utóbbi két évtizedben a CP-t kielégítő hatékonysággal és biztonsággal használták a súlyos ARDS-t okozó koronavírus-l (SARS-CoV-1), a közelkeleti légúti distressz szindróma hátterében álló koronavírus-betegség (MERS), valamint a HINl-influenza A pandémia során, ezért észszerúnek látszik a terápiás lehetôség alkalmazása súlyos/kritikus COVID-19-fertőzés kezelésére [1, 5-7]. A pandémia lefolyása során hétről hétre mind több és több beteg gyógyul fel a COVID19-ból, ezért a CP-terápia egyre jobban elérhető terápiás lehetőséget jelenthet a betegek számára. Ennek meg- felelően a Dél-pesti Centrumkórház Országos Hematológiai és Infektológiai Intézete (DPC-OHII) és az Országos Vérellátó Szolgálat (OVSZ) közremúködésével a CONTARST- (COmparing Novel Treatment strategies Against SARS-CoV-Two) vizsgálat keretében elindult a súlyos és kritikus COVID-19-fertőzöttek kezelésére a CP-terápiás program. Közleményünk megírásának célja az első két, hazánkban CP-vel sikeresen kezelt, kritikus állapotú COVID-19-fertőzött beteg kórtörténetének bemutatása.

\section{Módszer}

A CONTARST-vizsgálat (CP-terápiás karjának ETTTUKEB [Egészségügyi Tudományos Tanács-Tudományos és Kutatásetikai Bizottság] ügyiratszáma: IV/39371/2020/EKU) keretében a gyógyult COVID-19-fertőzésen átesett betegektől származó convalescens friss fagyasztott plazmával történő terápia (COVID-19-FFP) alkalmazásának indikációit súlyos ARDS-t okozó koronavírus-2 (SARS-CoV-2) polimeráz-láncreakció (PCR) pozitív betegekben 4 beválasztási kritérium szerint határoztuk meg. A vizsgálatba (1) súlyos COVID-19-et, (2) kritikus COVID-19-et, (3) súlyos COVID-19-et előre jelző rizikófaktor jelenléte és a citokinvihar kialakulásának kockázatára utaló egy vagy több laboratóriumi eltérés együttes jelentléte és (4) a másodlagos haemophagocytás lymphohistiocytosis/macrophagaktivációs szindróma (sHLH/MAS) fennállása esetén vehetők fel betegek. A 4 beválasztási kritérium részletes jellemzőit az 1. táblázat tartalmazza. A COVID-19-FFP alkalmazásához a további speciális kritériumok jelenléte is szükséges: az első tünetek jelentkezésétől kevesebb mint 14 nap teljen el, és a beteg még SARS-CoV-2-PCR-pozitív legyen. A COVID-19-FFP alkalmazásának kontraindikációját jelenti a 14 napnál régebben fennálló betegség, a 24 órán belüli, de maximum 48 órán belüli SARS-CoV2-PCR-negatív eredmény, az IgA- vagy haptoglobinhiány, a súlyos ismétlődő allergiás szövődmény vagy anaphylaxia a transzfúzió során, továbbá a folyadékterhelés elviselésének klinikai állapotot (TACO) rontó veszélye. A kritériumoknak megfelelően az első lépésben két kritikus COVID-19-fertőzött betegnél alkalmaztunk CP-terápiát. Klinikai információk a kórházi számítógépes rendszerből származó adatok összesítéséből, a képalkotó vizsgálatok eredményeiből, a gépi lélegeztetési paraméterekből, valamint a virológiai vizsgálatok és a terápiás lapok adatainak összegyújtéséből származtak. A vizsgálatba bevont betegek és a donorok - önrendelkező képességük korlátozottsága esetén jogi képviselőik - megismerték és aláírták a klinikai vizsgálat tájékoztatóját, és aláírásukkal igazoltan beleegyeztek a tanulmányban való részvételbe. A COVID-19-fertőzésből felépült önkéntes donorok jelentkezése a kórházból elbocsátott felépült betegek felkérésével és a különböző honlapokon és médiumokban közzétett elérhetőségek felhasználásával történt. A donorok aláírták a donációról szóló bele- 


\begin{tabular}{|c|c|}
\hline $\begin{array}{l}\text { Speciális kritériumok } \\
\text { a COVID-19-FFP-re }\end{array}$ & $\begin{array}{l}\text { 1) Az első tünetek jelentkezésétól kevesebb mint } 14 \text { nap telt el } \\
\text { 2) A beteg még SARS-CoV-2-PCR-pozitív }\end{array}$ \\
\hline 1. Súlyos COVID-19 & $\begin{array}{l}\text { (Bármelyik paraméter fennállása esetén) } \\
\text { 1) Légzésszám } \geq 30 / \text { perc, gyorsan romló vérgázérték }\left(\mathrm{PaO}_{2}<80 \mathrm{Hgmm} \text { körlevegön }\right) \\
\text { 2) Fizikális vizsgálattal hallható zörej és } \mathrm{SpO}_{2} \leq 93 \% \text { körlevegón vagy oxigénszükség- } \\
\text { let: Venturi-maszk }>50 \% \\
\text { 3) } \mathrm{PaO}_{2} / \mathrm{FiO}_{2} \leq 300 \mathrm{Hgmm} \\
\text { 4) } \mathrm{CT} \text {-vel: a tüdő́ben multilobularis laesiók vagy a tüdőinfiltrátumok } 50 \% \text {-os } \\
\text { progressziója } 48 \text { órán belül }\end{array}$ \\
\hline 2. Kritikus COVID-19 & $\begin{array}{l}\text { (Bármelyik fennállása esetén) } \\
\text { 1) } \mathrm{SpO}_{2} \leq 90 \% \text {, oxigénszükséglet: } \mathrm{FiO}_{2}>100 \% \text { mellett } \\
\text { 2) } \mathrm{PaO}_{2} / \mathrm{FiO}_{2} \leq 200 \mathrm{Hgmm} \\
\text { 3) Gépi lélegeztetést igénylö légzési elégtelenség } \\
\text { 4) Shock } \\
\text { 5) Kombinációja bármely szervi elégtelenséggel, amely intenzív osztályos ellátást } \\
\text { követel meg }\end{array}$ \\
\hline $\begin{array}{l}\text { 3. Súlyos COVID-19-et előre jelző rizikófaktor jelenléte } \\
\text { ÉS } \\
\text { citokinvihar-szindróma (cytokine release syndrome, } \\
\text { CRS) kialakulási kockázatának együttes fennállása }\end{array}$ & 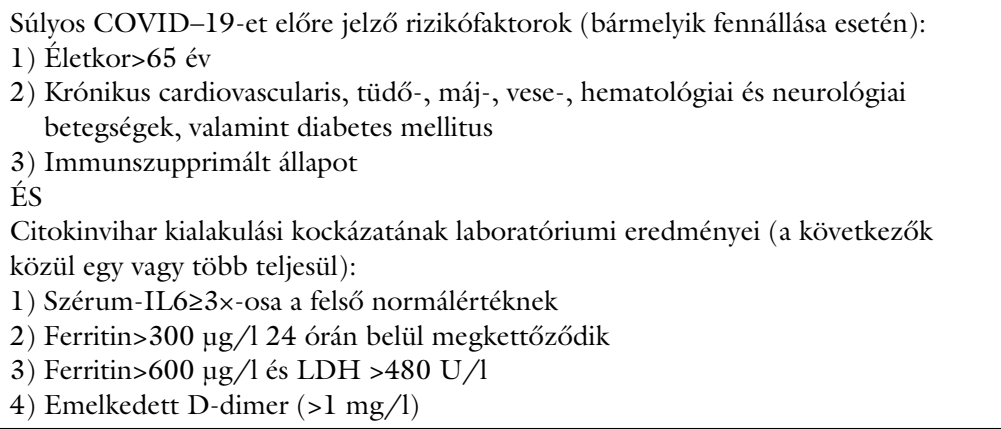 \\
\hline $\begin{array}{l}\text { 4. A COVID-19-hez társult másodlagos haemophagocy- } \\
\text { tás lymphohistiocytosis/macrophagaktivációs } \\
\text { szindróma (sHLH/MAS) }\end{array}$ & Ha az ún. HS-score >169 pont, akkor a kritériumok teljesülnek ${ }^{1}$ \\
\hline
\end{tabular}

${ }^{1}$ A csontvelői haemophagocytosis nem szükséges a HLH diagnózisához. A HS-score számításához online HS-score-kalkulátor rendelkezésre áll: http://saintantoine.aphp.fr/score/. Cytopeniák: hemoglobin 9,2 g/1 vagy kevesebb ( $\leq 5,71$ mmol/1), fehérvérsejtszám 5 G/1 vagy kevesebb, thrombocytaszám 110 G/l vagy kevesebb. Immunszuppresszió: HIV-pozitív vagy hosszú távú immunszuppresszív terápia (szteroidok, ciklosporin, azatioprin)

COVID-19 = koronavírus-betegség 2019; CT = számítógépes tomográfia; FFP = friss fagyasztott plazma; FiO 2 = belélegzett $\mathrm{O}_{2}$-koncentráció; $\mathrm{HIV}$ = emberi immunhiányt előidéző vírus; HLH = haemophagocytás lymphohistiocytosis; HS-score = haemophagocytás lymphohistiocytosis pontrendszer; IL6 = interleukin-6; $\mathrm{PaO}_{2}=$ parciális oxigénnyomás; PCR = polimeráz-láncreakció; SARS-CoV-2 = súlyos akut légzőszervi tünet-

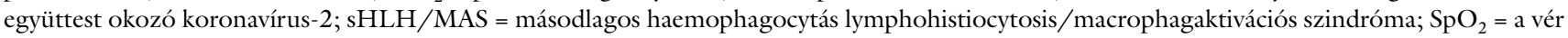
oxigéntelítettsége körlevegőn

egyező nyilatkozatot. A donációra való életkori alkalmasság általában 18 és 60 év között került meghatározásra, de biológiailag fitt és komorbiditással nem rendelkező személyek esetén a felső korhatár 70 év volt. Alkalmassá csak azok válhattak, akiknek a humán immundeficientiavírus (HIV-), hepatitis B-, hepatitis C- és syphilistesztjük negatív eredményt mutatott. A kutatási programba önkéntesen jelentkező, igazoltan COVID-19-en átesett személyek, ha legalább 2 hete panasz- és tünetmentesek voltak, kétlépcsős kivizsgáláson vettek részt. Az első lépcsőben - az előszürés során - orr-garat dupla mintavételből SARS-CoV-2-PCR (Nemzeti Népegészségügyi Központ, NNK és DPC-OHII), vírusspecifikus antitest vizsgálata (anti-SARS-CoV-2-ellenanyag mérése enzimhez kapcsolt immunszorbens-vizsgálattal [ELISA-módszerrel]; Alpha Diagnostic International, San Antonio, TX, USA), vérkép-, összefehérje-, IgG/IgA/IgM és labora- tóriumi vércsoportvizsgálat történt. Amennyiben a donor légúti mintavételből történő mindkét PCR-vizsgálata negatív, emellett ELISA-módszerrel kimutatható IgG-típusú ellenanyaga volt, nem állt fenn véradást kizáró tényező, a donor vénái megfelelőek voltak, és a klinikai vizsgálatba való beleegyezési nyilatkozatot aláírta, a vérplazmát adó személyt az OVSZ-be irányítottuk. Az OVSZ felvette a kapcsolatot a donorral, és az általa megjelölt donor-plazmaferézisközpontba (Plazma Pont) küldte. A második lépésben donorkivizsgálás és plazmaferézis történt. A donor-ferézisközpontban a jogszabályban elöírt vizsgálatokat követően megtörtént a plazmaferézis, $600 \mathrm{ml}$ plazma gyújtése hozzávetőleg 1 óra időtartam alatt. A végterméket besugárzásra, tárolásra és kiadásra átadták az OVSZ-nek. A készítmények $3 \times 200$ mL-es frakcióra osztva COVID-19 besugárzott FFP formájában kerültek kiadásra. Mindkét donor férfi (35, illet- 
ve 51 éves) volt. Mindketten viszonylag enyhe tünetekkel vészelték át a betegséget, lényeges társbetegség, rendszeres gyógyszerszedés egyiküknél sem volt. Mindketten légúti mintából SARS-CoV-2-PCR-negatívak voltak és ELISA-módszerrel IgG-típusú anti-SARSCoV-ellenanyagot termeltek. A plazmagyüjtésre az első tünetekhez képest 4 , illetve 5 hét múlva került sor. Szövődmény egyiküknél sem jelentkezett.

\section{Eredmények}

\section{A convalescens COVID-19-plazma recipienseinek kórtörténete}

\section{Első eset}

Ötvenkilenc éves férfi, akinek hosszabb távú anamnézisében hypertonia, inzulindependens diabetes mellitus, következményes retinopathia, néhány évvel korábban prostatacarcinoma miatt sugárterápia, krónikus gastritis és ez év eleje óta krónikus vesebetegség miatt intermittáló dialízisterápia szerepel. A beteg a CP elsố adagjának beadását megelőzően 12 nappal észlelte vizes hasmenését, amely miatt az aznapi dialíziskezelése el is maradt. Kétnapos panaszokkal a területileg illetékes sürgősségi ambulancián jelentkezett. Esetleges SARS-CoV-2-fertőzés miatt felvették a kórházba, majd elkülönítették. Megfigyelése alatt láz, hidegrázás alakult ki, laboratóriumi leleteiben lymphocytopeniát, emelkedett D-dimer-, laktátdehidrogenáz (LDH)-, kreatin-kináz-, trigliceridés transzaminázértékeket észleltek. Krónikus vesebetegségének megfelelően enyhe anaemia, emelkedett szérumkreatinin és hyperkalaemia jellemezte. A felső légutakból vett minta SARS-CoV-2-PCR-tesztje pozitív lett. Az akkor elvégzett mellkasröntgen csak mérsékelten fokozott bronchovascularis rajzolatot mutatott, infiltrátumra utaló jelet nem. Ezt követően a reguláris dialízis elvégzése céljából az enyhén zavart beteget áthelyezték a DPC-OHII Infektológiai Osztályára. A beteg érkezéskor láztalan volt, nem köhögött, köpete nem volt, torka nem fájt, gyakorlatilag panaszmentes volt. Az első tünetek kialakulása óta 3 nap telt el. Infektológiai kezelése másnapján került sor a mellkas natív CT-vizsgálatára, két nappal a negatív mellkasröntgenlelet után. A tüdőben jelzett eltérések, mint a perifériás túlsúlyú és peribronchovascularis szabálytalan konszolidátumok és tejüveghomály (GGO), vascularis kiszélesedés és interlobularis septummegvastagodás COVID-19-pneumonitisre jellegzetesek voltak. Az Infektológiai Osztályon hidroxiklorokin- és azitromicinkezelésben részesült, amelyet piperacillin-tazobaktám terápiával egészítettek ki. A beteg állapota újra romlott, száraz köhögés jelentkezett, az alkalmazott oxigénterápia ellenére hypoxia lépett fel, így Intenzív Osztályunkra helyeztük át a légzési elégtelen beteget, aki a felvételét követően nem sokkal gépi lélegeztetésre szorult, mély szedálás mellett [7]. Invazív hemodinamikai monitorizálást alkalmaztunk. Tekintettel a hosszabb ideje kimaradt hemodialíziskezelésre, valamint a hemodinamikai instabilitásra, vazopresszorigényre azonnali folyamatos venovenosus dialízist alkalmaztunk citrát-antikoaguláció mellett (Ci-Ca CVVHD). Természetesen mérlegelésre került az ún. CytoSorb-kezelés indikációjának lehetősége is [7]. Sikerült a beteg napi spontán vizeletürítésének mennyiségét megőrizni. Az ezt követő napokban a beteg subfebrilis volt, változó mennyiségü oxigénbevitelre szorult. A korábban álta-

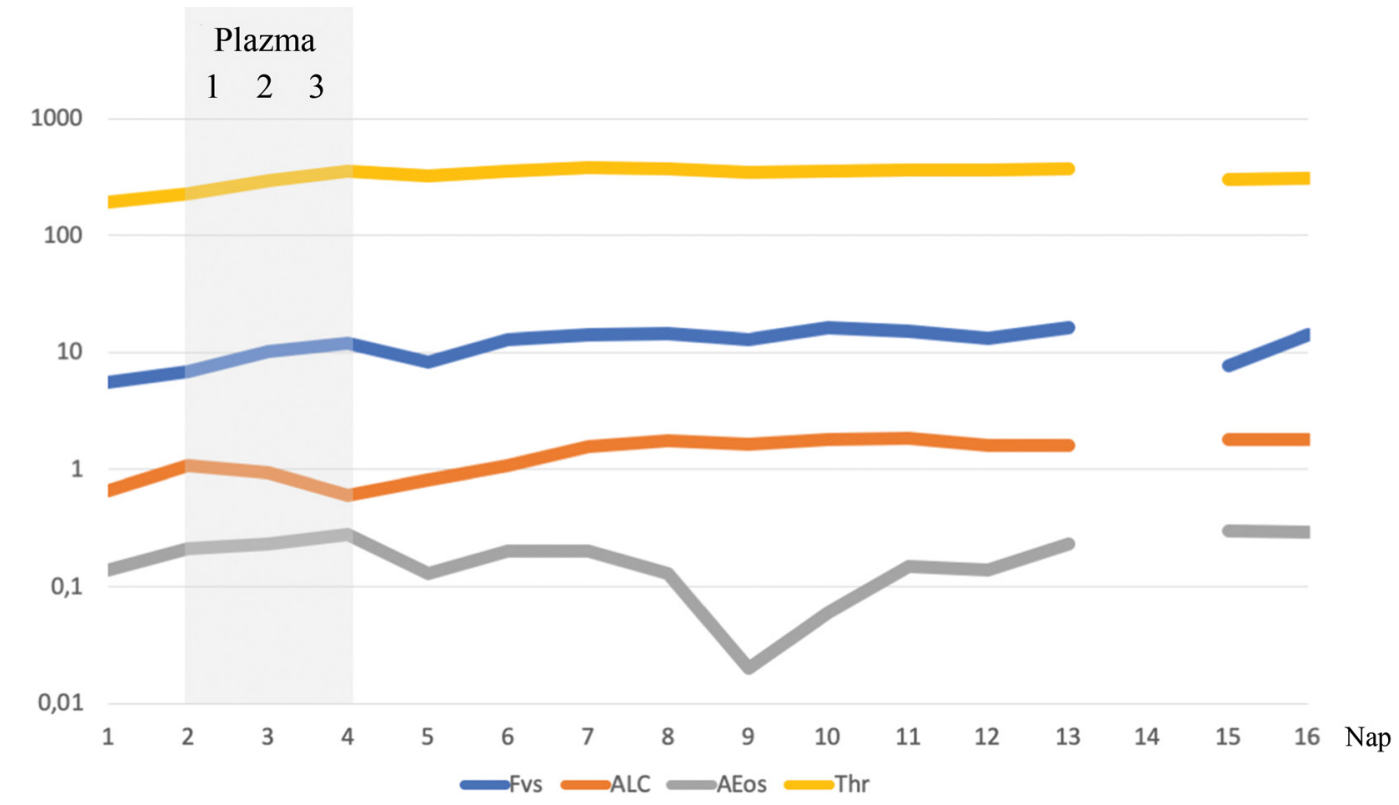

1. ábra $\quad$ Az első betegnél a convalescens plazma beadását követően mind a fehérvérsejt, mind az abszolút lymphocytaszám, illetve a thrombocytaszám megemelkedett

AEos = abszolút eosinophylszám $(\mathrm{G} / \mathrm{l}) ; \mathrm{ALC}=$ abszolút lymphocytaszám $(\mathrm{G} / \mathrm{l}) ;$ Fvs = fehérvérsejtszám $(\mathrm{G} / \mathrm{l})$; Thr = thrombocytaszám $(\mathrm{G} / \mathrm{l})$ 


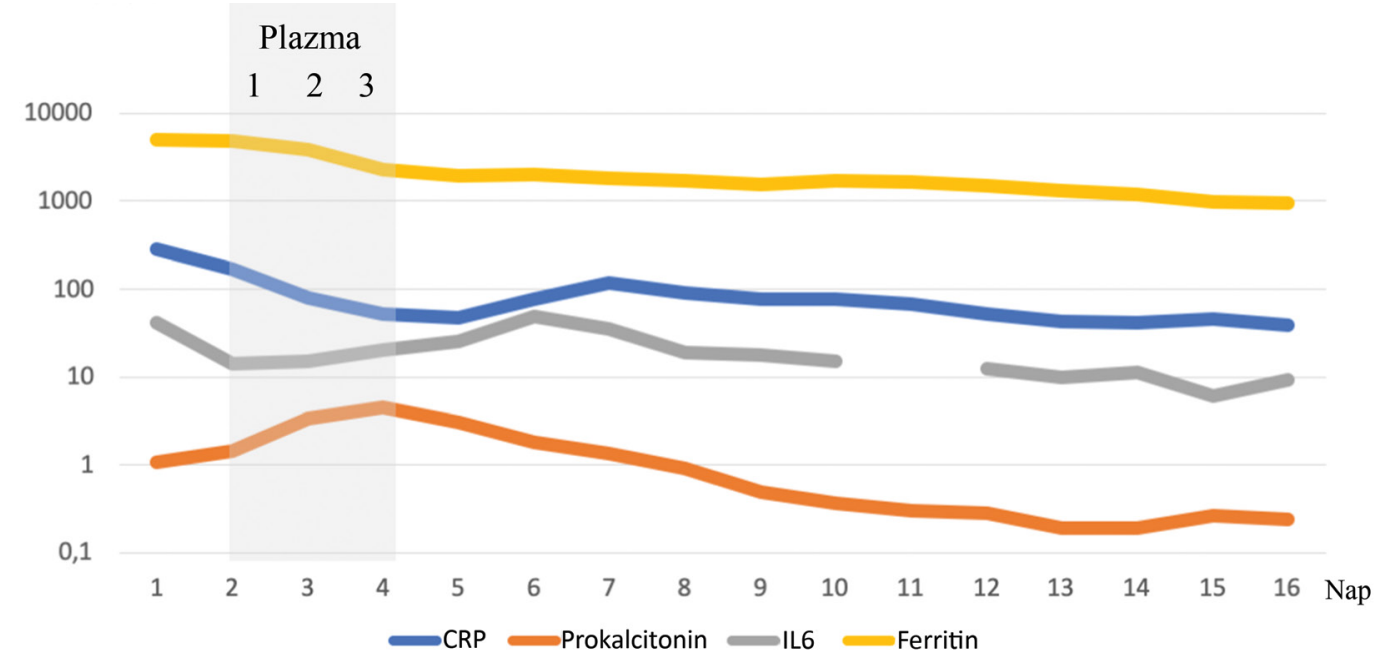

2. ábra

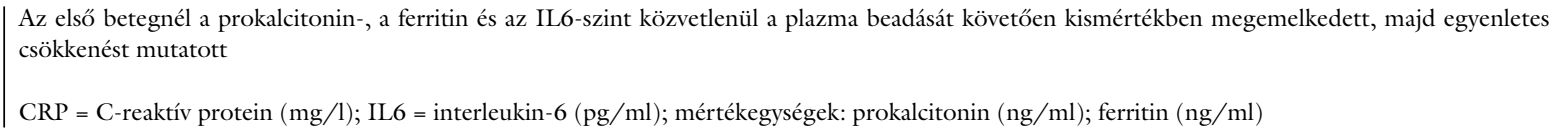

lunk kezelt COVID-19-betegekhez hasonlóan a beteg állapota látványos javulást nem mutatott. Ekkor merült fel, hogy betegünk - elsőként Magyarországon - CP-terápiában részesüljön. A vércsoportegyezés ismeretében, a vizsgálati protokollnak megfelelően, a beteg nyilatkozatképtelensége miatt megszereztük a beteg legközelebbi hozzátartozójának írásos beleegyezését. A fentieket követően betegünk 2020. 04. 23-án az első adag (200 $\mathrm{ml}$ ), majd ezt követően még két alkalommal COVID19-en átesett férfi donortól származó CP-vel terápiában részesült. A beteg vérképének és gyulladási paramétereinek a CP előtti, majd a beadást követő értékeinek változását a tizenötödik napig az 1. és 2. ábra szemlélteti. Az első CP beadására a beteg intenzív osztályos gépi lélegeztetésének negyedik napján került sor. Ezt követően egy héttel, összesen 11 nap gépi lélegeztetés után a beteget sikeresen extubáltuk. Azóta spontán légzése, oxigenizációja kielégítő. Az elvégzett kontroll-mellkas-CTvizsgálat a korábban leírt, GGO jellegű eltérések döntő többségének regresszióját mutatta. Másodlagos fertőzés miatt széles spektrumú antimikrobás terápiában részesült, amelyre jól reagált. A beteg felső légúti mintái még a vírus ürítésére utalnak, a vér PCR-vizsgálatának megfelelően azonban a viraemia megszűnt. A beteg rehabilitációját megkezdtük.

\section{Második eset}

A 72 éves férfi beteg heteroanamnézisében schizophrenia, másodlagos Parkinson-szindróma, hypertonia, cerebrovascularis, krónikus obstruktív tüdőbetegség (COPD), emphysema, atopiás dermatitis, köszvény, incontinentia szerepel. Az OMSZ szállította a szociális otthonban ápolt, biológiai kora alapján idős férfi beteget légzési elégtelenség miatt közvetlenül intézetünk Intenzív Osztályára. Szinte azonnal gépi lélegeztetést kellett alkalmaznunk [7]. A mély légúti minta SARS-CoV- 2-pozitivitása egyértelmúvé tette a COVID-19-pneumonitis jelenlétét. Eleinte magas oxigénbevitelre, illetve keringéstámogató vazopresszorterápiára szorult a beteg. Lélegeztethetősége nem igazán mutatott javulást az alkalmazott 'prone' pozíció ellenére sem. A tüdő fizikális állapota és a légzés mechanikája egyértelművé tette, hogy az úgynevezett L-fenotípusból H-fenotípusba váltott a beteg [8]. Ennek következtében az oxigénbevitelt emelni kellett, a $\mathrm{PaO}_{2} / \mathrm{FiO}_{2}$ aránya romlott. Az elvégzett kontrasztanyagos mellkasi CT-vizsgálat az antiXa-titer monitorizálása mellett alkalmazott, terápiás dózisú kis molekulatömegü heparinos (LMWH) kezelés ellenére jobb oldalon nem friss jellegü, az arteria pulmonalis fötörzsében macro-, illetve több lebenyt érintő segmentalis és subsegmentalis ágakban többszörös microembolisatiónak megfelelő kontrasztanyag-halmozásban

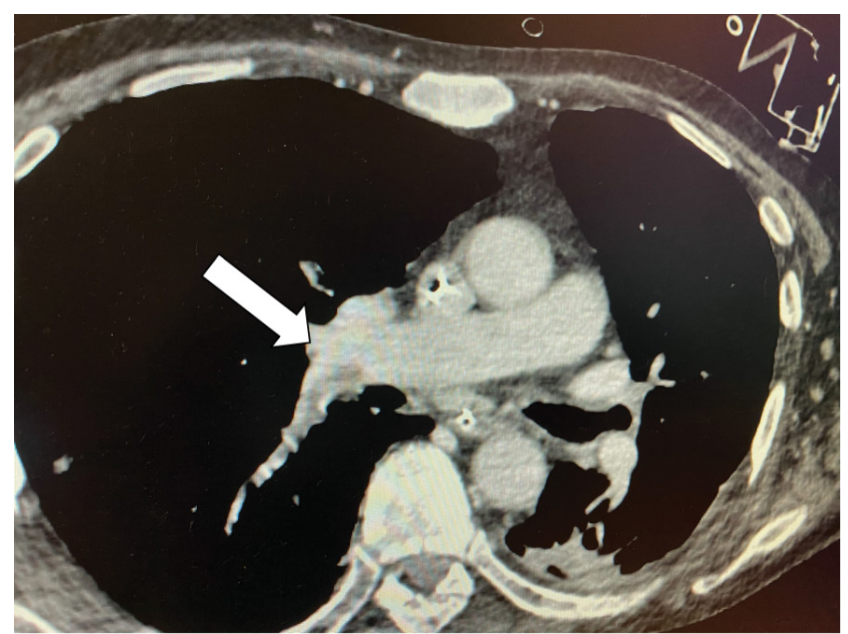

3. ábra

A második beteg jobb oldali arteria pulmonalisában elhelyezkedő thrombus. Megjegyzés: a nyíl az angiográfiás komputertomográfiával kimutatott thrombust mutatja 


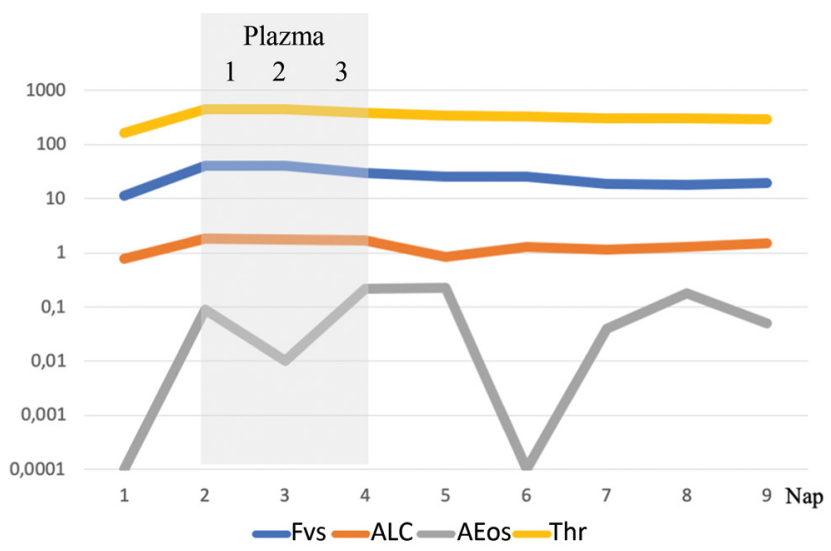

4. ábra $\quad$ A második betegnél a convalescens plazma beadását követően mind a fehérvérsejt-, mind az abszolút lymphocyta-, az abszolút eosinophyl-, illetve a thrombocyaszám látványosan megemelkedet

AEos $=$ abszolút eosinophylszám $(\mathrm{G} / \mathrm{l}) ; \mathrm{ALC}=$ abszolút lymphocytaszám $(\mathrm{G} / \mathrm{l}) ;$ Fvs = fehérvérsejtszám $(\mathrm{G} / \mathrm{l}) ; \mathrm{Thr}=$ throm bocytaszám $(\mathrm{G} / \mathrm{l})$

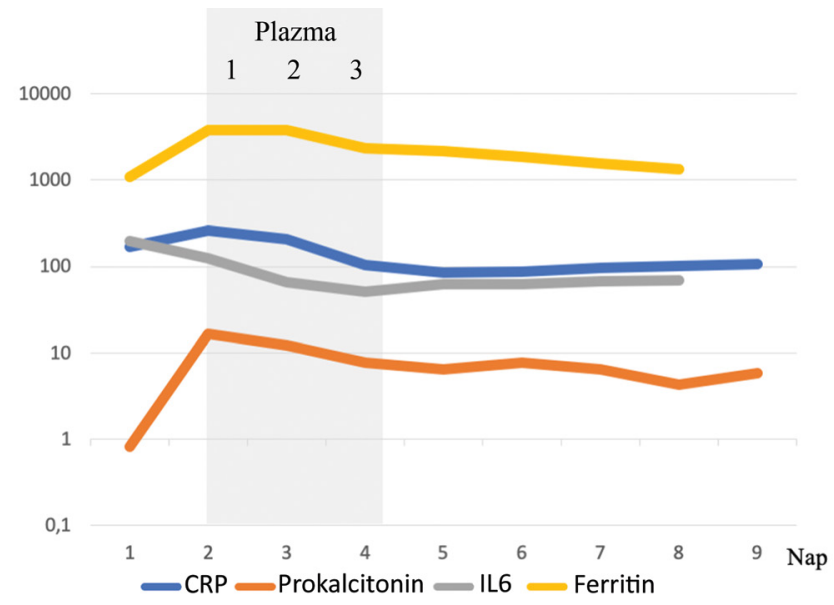

5. ábra

A második betegnél a CRP-, a prokalcitonin- és a ferritinszint közvetlenül a convalescens plazma beadását követően jelentős mértékben megemelkedett, majd egyenletes szignifikáns csökkenést mutatott

$\mathrm{CRP}=$ C-reaktív protein $(\mathrm{mg} / \mathrm{l}) ; \mathrm{IL} 6=$ interleukin- $6(\mathrm{pg} / \mathrm{ml}) ;$ mértékegységek: prokalcitonin $(\mathrm{ng} / \mathrm{ml})$; ferritin $(\mathrm{ng} / \mathrm{ml})$

elmaradó területeket igazolt. A tüdőparenchymában jelzett, részben konszolidatív, részben GGO és interstitialis jellegú eltérések morfológiája és lokalizációja is a COVID-19-infekció lehetőségét támasztotta alá (3. ábra). Hemodinamikai instabilitása miatt hosszan szorult változó mennyiségú vazopresszoros terápiára; átmenetileg pitvarfibrillációs arrhythmia lépett fel, láza, subfebrilitasa több napon át tartott az alkalmazott antimikrobás kezelés ellenére. Vesefunkciója a konzervatív terápiára lassan javult; a folyamatos vesepótló kezelés lehetősége többször felmerült, de végül nem szorult rá a beteg. A klinikai képet színezte a több napon át tartó, nehezen oldódó paralyticus ileus, majd a Clostridium difficile okozta enteritis. A multimorbid beteg esetében a vércsoportegyezés lehetőséget adott arra, hogy CP-terápiában részesüljön. Előzetes írásos beleegyezést követően a beteg 2020. 05. 03-án megkapta az első, majd az azt követő két napban a teljes adag CP-t. A beteg vérképének és gyulladási paramétereinek a $\mathrm{CP}$ előtti, majd a beadást követó értékeinek változását a 8 . napig a 4 . és 5 . ábra szemlélteti. A beteg izomerejének nagyfokú gyengesége miatt mútéti tracheostomát képeztünk. Ezt követően, az intenzív osztályos kezelésének 21., míg a CP harmadik, utolsó adagjának beadását követô 6 . napon a gépi lélegeztetést felfüggesztettük. A beteg alsó légúti mintája az utolsó $\mathrm{CP}$ beadását követô 5 ., intenzív osztályos kezelésének 20. napján vált negatívvá a SARS-CoV-2 szempontjából.

\section{Megbeszélés}

Közleményünkben két kritikus állapotú COVID-19fertőzött férfi beteg sikeres CP-kezelésének eredményét mutattuk be a klinikai állapot alakulása és a laboratóriumi eredmények által igazoltan. Mindkét beteg számos társbetegséggel rendelkezett, melyek közül kiemeljük a hypertoniát és a cardiovascularis betegséget. Egyiküknél a hosszú ideje fennálló diabetes mellitus talaján kialakult veseelégtelenség is gyarapította a rizikófaktorok számát. Mindkettőnél kétoldali tüdőinfiltrátum és súlyos légzési elégtelenség alakult ki, ami gépi lélegeztetés alkalmazását igényelte. A laboratóriumi paraméterek egyértelmúen alátámasztották a CRS fennállását az ARDS hátterében. Antivirális kezelésként az intézetünkben standard azitromicin- és hidroxiklorokin-kezelést alkalmaztuk. A gépi lélegeztetés 8. és 13. napján CP-transzfúziót adtunk $3 \times$ $200 \mathrm{ml}$ dózisban. A CP-kezelést követően a lymphocytopenia néhány nap alatt normalizálódott. A CRP-értékek kb. 50\%-os csökkenést mutattak, de a komorbiditások miatt fellépő szuperinfekciók hatására tartósan emelkedettek maradtak. Az emelkedett IL6-szint a CPkezelésre az első betegben átmenetileg emelkedett ugyan, ám azután csökkent; a második betegben lényegesen nem változott a szint. A ferritinszint az IL6-hoz hasonlóan viselkedett. Az első esetben az igen határozott D-dimer-emelkedés prompt választ mutatott a $\mathrm{CP}$ transzfúzióra. Mindkét betegnél a teljes dózisú $\mathrm{CP}$ beadását követően 6 és 11 nap elteltével a mesterséges lélegeztetést fel tudtuk függeszteni. Az első esetben a SARS-CoV-viraemia megszúnt, de a bronchoalveolaris minta elhúzódóan pozitív PCR-eredményt adott. A második betegnél a vírus ürítése megszúnt. Mindkét esetben kimutatható volt a SARS-CoV-2-IgG ELISAmódszerrel. Jelenleg a COVID-19 CP-terápiájáról korlátozott számú tudományos közlemény olvasható a nemzetközi szakirodalomban, melyek fóbb eredményeit a 2. táblázat mutatja be. Az elsőként publikált kínai közleményben 5 kritikus betegen alkalmaztak CP-t $1 \times 400$ $\mathrm{ml}$ dózisban [9]. A tünetek megjelenése és a CP alkalmazása között több mint 14 nap telt el. Négy betegnél az 
2. táblázat | Esetismertetések és kis betegcsoporton alkalmazott convalescens COVID-19 friss fagyasztott plazmával történő terápia eredményei SARS-CoV-2PCR-rel igazolt COVID-19-fertőzött betegekben

\begin{tabular}{|c|c|c|c|c|c|c|c|c|c|c|c|}
\hline Irodalom & $\begin{array}{l}\text { Életkor/ } \\
\text { Nem }\end{array}$ & $\begin{array}{l}\text { A betegség } \\
\text { súlyossága }\end{array}$ & $\begin{array}{l}\text { Antivirális } \\
\text { kezelés }\end{array}$ & Szteroid & CT & $\begin{array}{l}\text { A tünetek } \\
\text { és a CP } \\
\text { adása } \\
\text { között } \\
\text { eltelt idő } \\
\text { (nap) }\end{array}$ & $\begin{array}{l}\text { CP-dózis } \\
(\mathrm{ml})\end{array}$ & $\begin{array}{l}\text { CP adása } \\
\text { után a } \\
\text { SARS-CoV- } \\
\text { 2-PCR } \\
\text { negatív } \\
\text { (nap) }\end{array}$ & $\begin{array}{l}\text { CP adása } \\
\text { után } \\
\text { a CT } \\
\text { javulása } \\
\text { (nap) }\end{array}$ & $\begin{array}{l}\text { CP adása } \\
\text { után } \\
\text { extubá- } \\
\text { ció (nap) }\end{array}$ & Kimenetel \\
\hline \multicolumn{12}{|l|}{$\begin{array}{l}\text { Shen és } \\
\text { mtsai [9] }\end{array}$} \\
\hline 1. & $73 /$ ffi & Kritikus & $\begin{array}{l}\text { Lopinavir/ } \\
\text { ritonavir, } \\
\mathrm{IFN} \alpha \text {, } \\
\text { favipiravir }\end{array}$ & Igen & Nem & 24 & $1 \times 400$ & 12 & & - & $\begin{array}{l}\text { Stabil, gépi } \\
\text { lélegeztetés }\end{array}$ \\
\hline 2. & $60 / \mathrm{ffi}$ & Kritikus & $\begin{array}{l}\text { Lopinavir/ } \\
\text { ritonavir, } \\
\text { arbidol, } \\
\text { darunavir }\end{array}$ & Igen & Nem & 14 & $1 \times 400$ & 12 & & - & $\begin{array}{l}\text { Stabil, gépi } \\
\text { lélegeztetés }\end{array}$ \\
\hline 3. & $50 /$ nô & Kritikus & $\begin{array}{l}\text { Lopinavir/ } \\
\text { ritonavir, } \\
\mathrm{IFN} \alpha\end{array}$ & Igen & Nem & 22 & $1 \times 400$ & 3 & & 2 & Meggyógyult \\
\hline 4. & 36/nô & Kritikus & $\begin{array}{l}\text { IFN } \alpha, \\
\text { favipiravir }\end{array}$ & Igen & Nem & 21 & $1 \times 400$ & 3 & & 9 & Meggyógyult \\
\hline 5. & $60 / \mathrm{ffi}$ & Kritikus & $\begin{array}{l}\text { Lopinavir/ } \\
\text { ritonavir, } \\
\mathrm{IFN} \alpha\end{array}$ & Igen & Nem & 23 & $1 \times 400$ & 1 & & 9 & Meggyógyult \\
\hline \multicolumn{12}{|l|}{$\begin{array}{l}\text { Ahn és } \\
\text { mtsai [10] }\end{array}$} \\
\hline 1. & $70 / \mathrm{ffi}$ & Kritikus & $\begin{array}{l}\text { hCHQ, } \\
\text { lopinavir/ } \\
\text { ritonavir }\end{array}$ & Igen & $\begin{array}{l}\text { Kétoldali } \\
\text { infiltrátum }\end{array}$ & 22 & $2 \times 250$ & 16 & 16 & NA & Meggyógyult \\
\hline 2. & $67 / \mathrm{ffi}$ & Kritikus & $\begin{array}{l}\text { hCHQ, } \\
\text { lopinavir/ } \\
\text { ritonavir }\end{array}$ & Igen & $\begin{array}{l}\text { Kétoldali } \\
\text { infiltrátum }\end{array}$ & 7 & $2 \times 250$ & 14 & NA & 3 & Meggyógyult \\
\hline \multicolumn{12}{|l|}{$\begin{array}{l}\text { Duan és } \\
\text { mtsai [11] }\end{array}$} \\
\hline 1. & $46 / \mathrm{ffi}$ & Kritikus & $\begin{array}{l}\text { Arbidol, } \\
\text { ribavirin }\end{array}$ & Nem & $\begin{array}{l}\text { Kétoldali } \\
\text { infiltrátum } \\
+ \text { GGO }\end{array}$ & 11 & $1 \times 200$ & 1 & NA & 2 & $\begin{array}{l}3 \text { Meggyó- } \\
\text { gyult, } \\
7 \text { klinikai } \\
\text { javulás }\end{array}$ \\
\hline 2. & 34/nő & Súlyos & Arbidol & Nem & $\begin{array}{l}\text { Kétoldali } \\
\text { infiltrátum } \\
+ \text { GGO }\end{array}$ & 11 & $1 \times 200$ & 2 & NA & & NA \\
\hline 3. & $42 / \mathrm{ffi}$ & Kritikus & Arbidol & Igen & $\begin{array}{l}\text { Kétoldali } \\
\text { infiltrátum } \\
+ \text { GGO }\end{array}$ & 19 & $1 \times 200$ & 1 & NA & + & NA \\
\hline 4. & $55 /$ nő & Kritikus & Ribavirin & Igen & $\begin{array}{l}\text { Kétoldali } \\
\text { infiltrátum } \\
+ \text { GGO }\end{array}$ & 19 & $1 \times 200$ & 1 & NA & + & NA \\
\hline 5. & $57 / f f i$ & Súlyos & $\begin{array}{l}\text { Arbidol, } \\
\text { remdesivir } \\
\operatorname{IFN} \alpha,\end{array}$ & Igen & $\begin{array}{l}\text { Kétoldali } \\
\text { infiltrátum } \\
+ \text { GGO }\end{array}$ & 14 & $1 \times 200$ & 2 & NA & & NA \\
\hline 6. & 78/nő & Súlyos & Arbidol & Igen & $\begin{array}{l}\text { Kétoldali } \\
\text { infiltrátum } \\
+ \text { GGO }\end{array}$ & 17 & $1 \times 200$ & 2 & NA & & NA \\
\hline 7. & $56 /$ ffi & Súlyos & Arbidol & Igen & $\begin{array}{l}\text { Kétoldali } \\
\text { infiltrátum } \\
+ \text { GGO }\end{array}$ & 16 & $1 \times 200$ & 2 & NA & & NA \\
\hline
\end{tabular}


2. táblázat folyt.

\begin{tabular}{|c|c|c|c|c|c|c|c|c|c|c|c|}
\hline Irodalom & $\begin{array}{l}\text { Életkor/ } \\
\text { Nem }\end{array}$ & $\begin{array}{l}\text { A betegség } \\
\text { súlyossága }\end{array}$ & $\begin{array}{l}\text { Antivirális } \\
\text { kezelés }\end{array}$ & Szteroid & CT & $\begin{array}{l}\text { A tünetek } \\
\text { és a CP } \\
\text { adása } \\
\text { között } \\
\text { eltelt idő } \\
\text { (nap) }\end{array}$ & $\begin{array}{l}\text { CP-dózis } \\
(\mathrm{ml})\end{array}$ & $\begin{array}{l}\text { CP adása } \\
\text { után a } \\
\text { SARS-CoV- } \\
\text { 2-PCR } \\
\text { negatív } \\
\text { (nap) }\end{array}$ & $\begin{array}{l}\text { CP adása } \\
\text { után } \\
\text { a CT } \\
\text { javulása } \\
\text { (nap) }\end{array}$ & $\begin{array}{l}\text { CP adása } \\
\text { után } \\
\text { extubá- } \\
\text { ció (nap) }\end{array}$ & Kimenetel \\
\hline 8. & $67 / \mathrm{ffi}$ & Súlyos & Arbidol & Nem & $\begin{array}{l}\text { Kétoldali } \\
\text { infiltrátum } \\
\text { + GGO }\end{array}$ & 20 & $1 \times 200$ & 2 & NA & & NA \\
\hline 9. & 49/nő & Súlyos & $\begin{array}{l}\text { Arbidol, } \\
\text { oseltamivir, } \\
\text { peramivir }\end{array}$ & Nem & $\begin{array}{l}\text { Kétoldali } \\
\text { infiltrátum } \\
+ \text { GGO }\end{array}$ & 10 & $1 \times 200$ & 2 & NA & & NA \\
\hline 10. & $50 / \mathrm{ffi}$ & Súlyos & $\begin{array}{l}\text { Arbidol, } \\
\text { IFN } \alpha\end{array}$ & Igen & $\begin{array}{l}\text { Kétoldali } \\
\text { infiltrátum } \\
\text { + GGO }\end{array}$ & 20 & $1 \times 200$ & 5 & NA & & NA \\
\hline \multicolumn{12}{|l|}{$\begin{array}{l}\text { Ye és mtsai } \\
{[12]}\end{array}$} \\
\hline 1. & $69 / \mathrm{ffi}$ & Súlyos & - & - & $\begin{array}{l}\text { Kétoldali } \\
\text { infiltrátum }\end{array}$ & 32 & $3 \times 200$ & 9 & 4 & & Meggyógyult \\
\hline 2. & $75 /$ nő & Súlyos & - & - & $\begin{array}{l}\text { Kétoldali } \\
\text { infiltrátum }\end{array}$ & 26 & $2 \times 200$ & 9 & 6 & & Meggyógyult \\
\hline 3. & $56 /$ ffi & Súlyos & - & - & $\begin{array}{l}\text { Kétoldali } \\
\text { infiltrátum }\end{array}$ & 32 & $3 \times 200$ & NA & 6 & & Meggyógyult \\
\hline 4. & $63 /$ nő & Súlyos & Arbidol & - & $\begin{array}{l}\text { Kétoldali } \\
\text { infiltrátum }\end{array}$ & 30 & $1 \times 200$ & 1 & 4 & & Meggyógyult \\
\hline 5. & 28/nő & $\begin{array}{l}\text { Tünet- } \\
\text { mentes }\end{array}$ & - & - & Negatív & 32 & $1 \times 200$ & 1 & - & & Meggyógyult \\
\hline 6. & $57 / \mathrm{ffi}$ & Súlyos & - & - & $\begin{array}{l}\text { Kétoldali } \\
\text { infiltrátum }\end{array}$ & 49 & $1 \times 200$ & NA & 3 & & Meggyógyult \\
\hline
\end{tabular}

COVID-19 = koronavírus-betegség 2019; CP = convalescens plazma; CT = számítógépes tomográfia; ffi = férfi; GGO = tejüveghomály; hCHQ $=$ hidroxiklorokin; IFN $\alpha=$ inferferon-alfa; $\mathrm{NA}=$ nem elérhetó adat; PCR = polimeráz-láncreakció; SARS-CoV-2 = súlyos akut légzőszervi tünetegyüttest okozó koronavírus-2

IL6-szintek a CP beadását követően is tovább emelkedtek, a csúcsértékeket a 3. napra érték el, majd fokozatos elnyújtott csökkenést mutattak. A viraemia a SARSCoV-2-PCR szerint a 12 . napon negatívvá vált. A CP hatására három beteg meggyógyult, és további kettő állapota stabilizálódott [9]. Egy dél-koreai munkacsoport két kritikus állapotú esetet közölt $2 \times 250 \mathrm{ml} \mathrm{CP}$ alkalmazásával az első tünetek megjelenésétől számítva 7 és 22 nappal [10]. A többi publikációval ellentétben az IL6-szintek gyors normalizálódását észlelték. Mindkét beteget extubálták, és hazaengedték a kórházból [10]. Duan és mtsai 10, túlnyomórészt súlyos állapotú, CT-vel igazolt kétoldali infiltrátummal rendelkező, új típusú koronavírussal fertőzött beteget kezeltek $1 \times 200 \mathrm{ml} \mathrm{CP}$ transzfúzió adásával [11]. A CP adására három beteg meggyógyult, és hét esetben klinikai javulás következett be. A közlemény hátránya, hogy a citokinszintek és a SARS-CoV-2-PCR-eredmények alakulása nem érhető el, de kiemelendő, hogy a CT-morfológiai eltérések gyors regresszióját észlelték. Ye és mtsai - az általunk bemutatott két esethez hasonlóan - 200 ml-es egységenként alkalmaztak CP-terápiát túlnyomórészt súlyos COVID-19-betegeken. Hat betegből ötnél a CT-infilt- rátumok és az oxigenizáció gyors javulását észlelték, megakadályozva ezáltal a súlyos állapotból kritikus állapotba vezető progressziót [12]. CT-vizsgálattal a morfológiai eltérések gyors, dinamikus regresszióját figyelték meg. Figyelemre méltó, hogy kórházunk protokolljától és ajánlásaitól eltérően a tünetek megjelenésétől számítva több mint 30 nappal alkalmazták a CP-t. Véleményük szerint a CP gyulladásgátló hatása megakadályozhatja a CRS súlyosbodását vagy kialakulását. Az irodalomban közölt esetek alapján megállapítható, hogy a COVID-19 CP-terápiája hatékony lehetőség, és mellékhatást nem észleltek [9-12]. A CP hatékonyságának egyértelmú megítélését jelenleg korlátozza az infekció korai fázisában lévő betegek hiánya, az egyidejúleg alkalmazott többféle kezelés és a kis betegszám [1, 9-12]. A CP hatásmechanizmusaiban elsősorban az antitesttartalma által a vírus közvetlen neutralizációja emelhető ki, de antitestmediált folyamatok-úgymint a komplementaktiváció, az antitestfüggő sejtközvetített citotoxicitás (ADCC) és/vagy az antitestfüggő cellularis phagocytosis (ADCP) - szintén szerepet játszanak [1, 13]. Nem neutralizáló antitestek szintén a vírushoz kötődnek, de nem interferálnak in vitro rendszerekben a replikációképességgel, 
ami szintén elősegíti a fertőzésből való felépülést. Azonban számos, jelenleg nem teljesen feltérképezett paramétert is figyelembe kell venni a COVID-19 CP klasszikus passzív immunterápiaként különböző fertőzések prevenciójában és kezelésében. Luke és mtsai metaanalízisében történelmi utazást tehetünk az influenzavírus okozta „spanyolnátha” idejére, amikor 1918 és 1925 között 1703 betegen, influenza convalescens vérkészítményt kapott egyénekben 21\%-os $(\mathrm{p}<0,001)$ csökkenést találtak a halálozási esetek arányában [14]. Az utóbbi 2 évtizedben a CP-t sikeres használták a SARS-CoV-1-, a MERS- és a HINl-pandémia során, kielégítő hatékonysággal és biztonsággal [6]. Mivel a SARS-CoV-1, a MERS és a COVID-19 virológiai és klinikai jellemzői hasonlóak, a CP ígéretes terápiás lehetőség lehet a COVID-19 esetében is. A COVID-19-fertőzésből felépült betegek magas neutralizálóantitest-titerrel ideális donorok a plazmaterápiához. A magas neutralizálóantitest-tartalmú plazma képes eradikálni a vírust a keringésből és a tüdőszövetből. A CP-terápia hatékonyságának legfontosabb tényezője a neutralizálóantitest-titer, melynek szerepére számos kínai közlemény hivatkozik [9]. 2020. március 24-én az USA Élelmiszer-biztonsági és Gyógyszerészeti Hivatala (FDA) publikálta elóírásait a vizsgálat alatt álló CP-alkalmazásról COVID-19 esetén [13]. A vírusneutralizációs vizsgálatok a körülményességük és speciális szakértelemigényük miatt nem alkalmasak nagy áteresztőképességú, tömeges donorplazmavizsgálatra, és széles körben nem is érhetők el. Ezenkívül a teljes anti-SARS-CoV-2-antitest-titer és a neutralizáló SARS-CoV-2 közötti kapcsolat jelenleg még nem tisztázott [13]. A levett vérplazma kvalitatív és kvantitatív vírusellenes IgG-tartalmának és titerének felmérésére ELISA- és EIA- (enzim-immunoassay) módszereket használunk. Azonban a tünetmentesen vagy csak enyhe tünetekkel átvészelt betegséget követően megfelelő antitesttiter ritkán alakul ki. Továbbá, a súlyosabb tünetekkel lezajlott betegséget követően számíthatunk inkább megfelelő antitesttiter kialakulására, de ilyen esetekben is legalább az esetek egyharmadában alacsony az antitesttiter, és csak rövid ideig, kb. 3-4 hónapig marad fenn. Számos egyéb kérdés is tisztázásra vár. Vajon a teljes immunglobulinszintet vagy immunglobulin-alcsoportokat kell-e vizsgálni, illetve hogy melyik antigén ellen termelődött immunfehérje a legfontosabb a vírus eliminációja szempontjából. A legtöbb módszerrel a 'spike' vagy S-fehérje-ellenes antitest vizsgálható. Az adatok korlátozottak ugyan, de a tünetek kezdetétól számított 8-21 nap között figyelték meg az antitestek megjelenését [13]. A CP-terápia a vérellátó és plazmaferézis-központoknak jelentős infrastrukturális kihívást jelent, a donorok szervezése, a szűrés, a plazmakészítmény előállítása és a logisztikai követelmények miatt. A CP-kezeléssel kapcsolatban a nem infekciós veszélyek közül a transzfúzióhoz kapcsolódó keringés-túlterhelés (TACO) és a transzfúzióhoz kapcsolódó heveny tüdősérülés (TRALI) említhető. Specifikus rizikó lehetne a SARS-CoV-2-fertőzés transzfúziós átvitele. Ez teoretikus, mert soha nem jelentették még a légúti vírusfertőzés transzmisszióját transzfúzióval [3]. Kínában 4995, tünetmentes donáció közül 0,02\%-ban találtak SARS-CoV-2-RNS-t [15]. További megfontolást igényel az ún. antitestfüggő erősítés (antibody-dependent enhancement, ADE) létezésének teoretikus rizikója, mely szerint az antitest potencírozza a fertőzést [16]. Mind ez idáig azonban CP adásakor ADE-t nem közöltek SARS-1-, MERS- és az eddig ismert COVID-19-esetekben. A CP-terápia alkalmazásakor a COVID-19-et jellemző CRS-ben felmerül egy további kérdés, melyet a hematológiai gyakorlat válaszolhat meg. Ha allogén haploidentikus őssejt transzplantáció esetén CRS alakul ki, akkor 48-62 órát kell áthidalnunk, mert alkalmazásra kerül a nagy dózisú ciklofoszfamid-, majd a takrolimusz- és mikofenolát-mofetil-immunszuppresszió, amely végleg lehüti a CRS-t. Ennek megfelelően a COVID-19 okozta CRS alternatívájaként, ha tocilizumabot, IVIG-et vagy CP-t alkalmazunk, akkor racionális érv a konszolidatív terápia alkalmazása, melynek a legkézenfekvőbb jelöltje lehet a jelátviteli mechanizmust gátló JAK/STAT-gátló alkalmazása [4]. A fentiek alapján megfontolandó terápiás alternatíva lehet a CP alkalmazását követően a JAK/STAT-gátló ruxolitinib vagy baricitinib konszolidációs kezelés alkalmazása.

\section{Következtetés}

A rendelkezésre álló adatok alapján megállapítható, hogy a CP-kezelés hatékony terápiás stratégia a súlyos és kritikus állapotú betegek kezelésében. Az általunk kezelt betegeknél az IL6-szint viselkedése változó volt, de a CP beadását követően az első betegnél átmenetileg emelkedett, a második betegben lényegesen nem változott a szint. Az idézett közlemények egyikében sem számoltak be súlyos vagy halált okozó szövődmények jelentkezéséről. A CP alkalmazása hatékonyan adályozza meg a kritikus állapotba való progressziót, illetve a már kritikus állapotba került betegeknél a gépi lélegeztetés megszüntetését is lehetővé tette. Saját tapasztalataink és a szakirodalmi adatok feldolgozása egyaránt arra hívja fel a figyelmet, hogy a CP-kezelést minél előbb kell alkalmazni, lehetőleg az első tünetek megjelenésétől számított 14 napon belül. A gyors állapotromlás időszakára esik a CRS első szakasza, amikor a gyors beavatkozás (CP, IL6-ellenes antitest, JAK/STAT-gátlás) gátat szabhat a citokinvihar kiteljesedésének és a halálos szervi károsodások kialakulásának. A rendelkezésre álló adatok alátámasztják a CP-terápia hatékonyságát és biztonságosságát a súlyos és kritikus COVID-19-fertőzött betegek kezelésére. További lehetőség a CP-terápia hatékonyságának konszolidálása az ún. JAK/STAT-jelátvitelt gátló kezelés által. 
Anyagi támogatás: A közlemény megírása támogatás nélkül történt.

Szerzői munkamegosztás: B. I. és G. L. azonos mértékben járult hozzá a közlemény elkészítéséhez. B. I.: Adatgyưjités, irodalomkutatás, részvétel a beteg kezelésében, a kézirat megírása, szerkesztése. G. L.: Adatgyújtés, irodalomkutatás, a kézirat megírása, szerkesztése. R. M., L. B.: Adatgyưjtés, részvétel a beteg kezelésében, a kézirat elkészítésében. B. G., R. P.: Részvétel a kézirat elkészítésében. H. L., M. E.: Részvétel a beteg kezelésében, a kézirat elkészítésében. N. S.: Adatgyüjtés, részvétel a donorok szervezésében, kivizsgálásában, a plazmakészítmény feldolgozásában, a kézirat elkészítésében. S. G.: Részvétel a beteg kezelésében, a kézirat elkészítésében. S. J., Sz. J.: Adatgyüjtés, részvétel a kézirat elkészítésében. Sz. M.: Részvétel a donorok szervezésében, kivizsgálásában, a plazmakészítmény feldolgozásában, a kézirat elkészítésében. V.-N. I.: A kutatási konzorcium vezetője, részvétel a kézirat elkészítésében és javításában. A cikk végleges változatát valamennyi szerző elolvasta és jóváhagyta.

Érdekeltségek: A szerzőknek nincsenek a közleménnyel összefüggő érdekeltségeik.

\section{Irodalom}

[1] Váradi A, Ferenci T, Falus A. The coronavirus-induced COVID-19 pandemic. Previous experiences and scientific evidences at the end of March, 2020. [A koronavírus okozta COVID-19-pandémia. Korábbi tapasztalatok és tudományos evidenciák 2020. március végén.] Orv Hetil. 2020; 161: 644651. [Hungarian]

[2] Zhang $\mathrm{C}, \mathrm{Wu} \mathrm{Z}, \mathrm{Li}$ JW, et al. The cytokine release syndrome (CRS) of severe COVID-19 and interleukin-6 receptor (IL-6R) antagonist tocilizumab may be the key to reduce the mortality. Int Antimicrobiol Agents 2020 Mar 29: 105954. Doi: 10.1016/j.ijantimicag.2020.105954. [Epub ahead of print]

[3] Zhang W, Zhao Y, Zhang F, et al. The use of anti-inflammatory drugs in the treatment of people with severe coronavirus disease 2019 (COVID-19): the experience of clinical immunologists from China. Clin Immunol. 2020; 214: 108393. Doi: 10.1016/ j.clim.2020.108393.

[4] Lakatos B, Gopcsa L, Gondos E, et al. Anti-cytokine therapy in novel coronavirus disease (COVID-19) - the first administration of tocilizumab in Hungary at a department of infectology. [Citokinellenes terápia az új típusú koronavírus okozta meg- betegedés (COVID-19) kezelésében - tocilizumab elsőként való alkalmazása az infektológiai osztályon.] Orv Hetil. 2020; 161: 1071-1078. [Hungarian]

[5] Mair-Jenkins J, Saavedra-Campos M, Baillie JK, et al. The effectiveness of convalescent plasma and hyperimmune immunoglobulin for the treatment of severe acute respiratory infections of viral etiology: a systematic review and exploratory meta-analysis. J Infect Dis. 2015; 211: 80-90.

[6] Hung IF, To KK, Lee CK, et al. Convalescent plasma treatment reduced mortality in patients with severe pandemic influenza $\mathrm{A}$ (H1Nl) 2009 virus infection. Clin Infect Dis. 2011; 52: 447456.

[7] Fülesdi B, Sárkány P, Szentkereszty Z, et al. Challenges of intensive care and anesthesiology related to COVID-19 pandemic. Practical considerations. [Az aneszteziológiai és intenzív ellátás kihívásai a COVID-19-fertőzéssel kapcsolatban. Gyakorlati ajánlás.] Orv Hetil. 2020; 161: 652-659. [Hungarian]

[8] Gattinoni L, Chiumello D, Caironi P, et al. COVID-19 pneumonia: different respiratory treatments for different phenotypes? Int Care Med. 2020 Apr 14. Doi:10.1007/s00134-020-06033-2. [Epub ahead of print]

[9] Shen C, Wang Z, Zhao F, et al. Treatment of 5 critically ill patients with COVID-19 with convalescent plasma. JAMA 2020; 323: 1582-1589.

[10] Ahn JY, Sohn Y, Lee SH, et al. Use of convalescent plasma therapy in two COVID-19 patients with acute respiratory distress syndrome in Korea. J Korean Med Sci. 2020; 35: el49.

[11] Duan K, Liu B, Li C, et al. Effectiveness of convalescent plasma therapy in severe COVID-19 patients. Proc Natl Acad Sci USA 2020; 117: 9490-9496.

[12] Ye M, Fu D, Ren Y, et al. Treatment with convalescent plasma for COVID-19 patients in Wuhan, China. J Med Virol. 2020 Apr 15. Doi: 10.1002/jmv.25882. [Epub ahead of print]

[13] Bloch EM, Shoham S, Casadevall A, et al. Deployment of convalescent plasma for the prevention and treatment of COVID-19. J Clin Invest. 2020 Apr 7. Doi: 10.1172/JCI138745. [Epub ahead of print]

[14] Luke TC, Kilbane EM, Jackson JL, et al. Meta-analysis: convalescent blood products for Spanish influenza pneumonia: a future H5Nl treatment? Ann Intern Med. 2006; 145: 599-609.

[15] Chang L, Zhao L, Gong H. Severe acute respiratory syndrome coronavirus 2 RNA detected in blood donations. Emerg Infect Dis. 2020; 26(7). Doi: 10.3201/eid2607.200839.

[16] Fleming AB, Raabe V. Current studies of convalescent plasma therapy for COVID-19 may underestimate risk of antibody-dependent enhancement. J Clin Virol. 2020; 127: 104388. Doi: $10.1016 /$ j.jcv.2020.104388.

(Gopcsa László dr., Budapest, Albert Flórián út 5-7., 1097 e-mail: laszlogopcsa@yahoo.com)

A cikk a Creative Commons Attribution 4.0 International License (https://creativecommons.org/licenses/by/4.0/) feltételei szerint publikált Open Access közlemény, melynek szellemében a cikk bármilyen médiumban szabadon felhasználható, megosztható és újraközölhető, feltéve, hogy az eredeti szerző és a közlés helye, illetve a CC License linkje és az esetlegesen végrehajtott módosítások feltüntetésre kerülnek. (SID_1) 